\title{
Application Research on Land E-commerce Crowd Funding Pattern in Land Circulation and Land Crowd Funding
}

\author{
Yubing Yang, a , Zhanping $\mathrm{Li}^{1, \mathrm{~b}}$, and Shui Wang ${ }^{1, \mathrm{c}}$ \\ ${ }^{1}$ School of Ningbo Dahongying University, Ningbo 315175, China

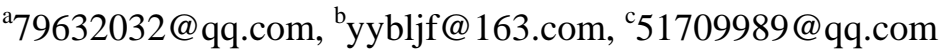

Keywords: land e-commerce crowd funding model, land transfer, land crowd funding

\begin{abstract}
With the rapid development of Chinese society and economy, rural economy has also made great progress. As an important component of rural social and economic development, land transfer in rural areas is significantly affected by the rapid development of Internet economy. Under the influence of Internet technology and concept, land e-commerce crowd funding model has taken form. However, no in-depth academic study on such model has been found. Therefore, this paper analyzes the development and application of such new-type land transfer model - land e-commerce crowd funding in the "Internet plus" era of China at present. It mainly introduces the development features and reasons of China's land e-commerce crowd funding model, analyzes the functions of such model in details and gives suggestions and countermeasures for the model's development so as to provide practical and theoretical references for the development of China's land e-commerce crowd funding model.
\end{abstract}

\section{Introduction}

With the rapid development of Chinese Internet economy, Chinese traditional agricultural land circulation pattern obtains great changes. According to Suggestions on Leading Rural Land Management Rights to Transfer and Develop the Agricultural Scale Operation Orderly to A Certain Extent issued in 2014 by General Office of the State Council of China, China implements the separation between rural land ownership, land contract right and land management right by insisting the collective ownership of rural land and further leads the management rights of rural land to transfer fluently and orderly. Affected by such policy, a new land dispersion pattern appears in China, that is, land e-commerce crowd funding pattern. At present, it has developed to be a major development trend that power grid gets involved in rural land circulation. This paper mainly carries out research and analysis of land e-commerce crowd funding pattern's role and application in Chinese current rural land circulation and crowd funding, further providing references for Chinese rural land circulation's development in the future.

\section{The Development Status of Chinese Rural Land Circulation Pattern}

Under the development of Chinese current Internet economy, apart from the traditional rural land circulation patterns, China has developed some totally new land circulation patterns. Now in the following, we will carry out analysis and introduction of Chinese current rural land circulation patterns.

\subsection{Land E-commerce Crowd Funding Pattern}

In Chinese current agricultural industry structure chain, the main processes of agricultural production and management are before-production, production, processing, circulation and consumption. The land e-commerce crowd funding pattern directly completes the production and consumption of agricultural products by saving the processing and circulation link in agricultural chain. By this pattern, farmers achieve farm production fund mainly by land crowd funding renting, 
which can eliminate the risks for farmers in their sales of farm products and save the related costs spent in the links of farm product storage and logistics at the same time, further achieving growth in farmers' income and reducing the costs of food for urban residents. For example, "Family Farm" rising in Shaoxing City of Zhejiang Province where 600yuan can be spent to subscribed to land for farming. Land dispersion patter mainly refers to that farmers, contractors sublease their own lands dispersedly to urban residents through the means of being introduced by their acquaintances or network, and the urban residents renting lands can plant by themselves or act as an agent during which farmers and contractors will carries out unified management of them. Finally, the farm products will directly be given to the renter. This new land circulation pattern has been applied in many regions. It connects the planter and the consumers of farm products together directly, raising farmers' income to maximum extent. But there are also some shortages in this pattern, for example, lands' being renting out disparately is carried out mostly through acquaintances' introduction and it is hard for the information of lands' being rent out to be widely spread, so certain scale is hard to develop. Meanwhile, as there is a lack of platforms of unified management and quality guarantee system, it will be impossible to form a healthy trust mechanism between farmers, contractors and urban renters and to guarantee the final implementation effect.

\subsection{Land Shareholding System}

Land shareholding system mainly refers to renters convert the land contracting and management rights into equity and then carry out agricultural cooperative operation in order to implement large-scale agricultural production. Meanwhile, it is also available for renters to get in with land and establish joint-stock companies or cooperatives and then carry out agricultural production and management. In such land circulation pattern, there are two modes of getting in generally: one is to join industrial and commercial enterprises or other production and trading organizations to achieve dividends or bonus; the other is the agricultural production contractors all voluntarily get in with their own contracting and management rights and then finally carry out specialized agricultural cooperative production.

\subsection{Subcontracting}

Subcontracting mainly refers to that there is no changes in the land contracting relationship and the rural land contractors subcontract their total or partial land management rights to others for agricultural production or management within a certain period while the part receiving the land transferring have to take responsibility for the other party as required, thus the original contractor can perform the contractual obligations of land contracting instead of the original contract-issuing party. There is no direct contractual relation between the transferor and the party accepting the transfer but relation of rights and obligations.

\subsection{Renting}

Rural land contractors rent their total or partial land contracting management rights to another for agricultural production within a certain period of time, and the renter is required to pay certain rent for the leaser. After the rural land's being rented, there is no change in land contractual relation and the original rural land contractor will continue to fulfill his relevant obligations and rights in the land contracts. This rural land circulation pattern has developed to be of scale and organization from its spontaneity and dispersibility.

\subsection{Exchange}

Exchange is a land contracting management rights circulation pattern in a lower level, more common in rural. Farmers exchange the land with each other aiming to meet their needs of farming or others after obtaining the other party's permission. This pattern is actually exchange of each land contracting management rights, requires the two parties to contract land contracting agreement in the implementation process, or there will be land disputes. However, in its actual development, many farmers mainly adopt the means of verbal agreement, which exists some hidden trouble and 
shortcomings.

\section{Application of Land E-commerce Crowding Pattern's Role}

\subsection{Enlarging Rural Land Circulation Scope}

In the past, Chinese rural land circulation is only carried out between the local relatives, friends and acquaintances. But the circulation of rural land can be implemented globally by modern internet technology when land e-commerce gets into Chinese rural land circulation. Taking the project “Gathering Land” of March, 2014 for example, its land of 465mu had been sold out within only five days since its sales online. The project's exposure clicks reach more than 500 million with 400 thousand people consulting. The subscribers of the land circulation project are mainly from Jiangxi, Zhejiang, Shanghai and Anhui in China. Land e-commerce circulation pattern can bring the current Internet technology's advantages into full play, achieving Chinese rural land resources' optimal allocation nationally and enlarging the scope of Chinese rural land circulation.

\subsection{Making Up the Shortfall in Rural Economic Development Funds}

Another significantly important challenge Chinese current rural economic development faces is the problem of fund shortage, but land e-commerce crowd funding pattern can just make up the shortfall in Chinese agricultural production and development, techniques and talents by making use of the advantages of internet technology and getting in agricultural production in the means of internet finance. Represented by "Gathering Land", rural land e-commerce crowding pattern gathers the idle money in society and invest it into farm production mainly by using the mode of internet pattern. In this pattern, the funds invested in land circulation can be used to buy agricultural implements, build water conservancy projects, strengthening the construction and development of rural infrastructure. Information can be increased in rural areas and modern agricultural production methods applied in agricultural production and construction.

\subsection{Increasing Farmers’' Income}

The implementation of land e-commerce crowd funding pattern can help farmers gather the idle lands together for land circulation and then obtain more income. The income not only includes the rent in their own rural production, but also that obtained by working in the land having been circulated out. In addition, based on this pattern, farmers can also provide the urban tourists services of beverage and housing by opening agritainment and further obtain more nonfarm income. Meanwhile, this pattern can also attract more migrant workers to return their hometown and start entrepreneurship. Solving the problems rural children's being left behind and elderly's being of empty-nest. Land e-commerce crowd funding pattern gathers some scattered lands together by means of short-term rent, quickening land circulation and helping farmers develop farm products of higher quality. At the same time, farmers represented by Jixi can obtain rent income of 800yuan each mu land and salary income of 2500yuan each month by doing work for others.

\subsection{Promoting Chinese Rural Industrial Structure}

At present, Chinese agricultural product structure is simplistic and severe damages exist in agricultural resources. Many rural areas in China are of beautiful scenery with rich agricultural resources and agricultural products of original ecology. But many villages don't realize their own advantages where the farm products are without name recognition and agricultural industrial structure is very simplistic. Affected by unreasonable production means, Chinese partial rural areas are obstructed in rural production development. Farmers can achieve their order-oriented production and development, the local agricultural resources be optimized, farm products' popularity be expanded and agricultural industrial structure be optimized by land e-commerce crowd funding pattern. 


\section{Suggestions on The Development of Land E-commerce Crowd Funding Pattern}

Land e-commerce crowd funding pattern is a newly land circulation model and it will face many problems in its development process, so it is required to adopt various measures to promote Chinese land e-commerce crowd funding pattern's development.

\subsection{Establishing Monitoring Mechanism in The Process of Platform Agricultural Products' Production}

In the process of developing land e-commerce crowd funding pattern, platform agricultural product production monitoring mechanism is required. According to customers' actual requirements, platform agricultural product production monitoring mechanism is gradually improved through setting up monitoring equipment and the rules of "acting supervisor".

\subsection{Establishing Credit Evaluation Mechanism}

The establishment of credit evaluation mechanism is of great significance to land e-commerce crowd funding pattern. The evaluation mechanism commonly applied in Taobao can be used to grade the services the two parties participating in land circulation provide and their integrity.

\subsection{Quickening Confirmation of Rural Land Right, Land Registration and Certification}

To make more full use of the role of land e-commerce crowd funding pattern, it is required urgently to solve the short-termism problem of Chinese rural land circulation while the key to solve this problem is to put rural land property right into practice. Therefore, it is required urgently to carry out the work of confirmation of rural land contracting and management right, land registration and certification to further promote land e-commerce crowd funding pattern's working fluently. On the basis of being pursuant to the law, voluntary and fee-based, the long-term development of Chinese rural land contractor and farm household land circulation are to be achieved based on the two parties' fair consultations.

\section{Summary}

Land circulation reform is a major measure to solve rural land operation system and realize farmland scale. It helps agricultural industrial development, greatly significant to realize agricultural modernization and socialism new countryside construction. Land e-commerce crowd funding pattern is a relatively advanced development mode in Chinese rural land circulation and land crowd funding, but it meets China's relevant requirements of land circulation policies. On the basis of innovating rural industrial chain, it plays a significant role in ensuring rural farmers' economic income worthy of promotion and usage to get residents of different cities and towns into rural production, reducing the risks in rural agricultural project management by the means of dispersive crowd funding. Under the background of the participation of Internet + in rural economic development, it is necessary to strive to develop this land circulation pattern and combine traditional agriculture with the concept of modern economic development to improve the efficiency of Chinese agricultural production.

\section{Acknowledgements}

Ningbo soft science research project funding project (No. 2015A10073), Ningbo technology and enriching project (No. 2016C10019).

\section{References}

[1] Guifang Hu, Yanrong Wang. Exploration of Developing Modern Agriculture by Combining Land Circulation and E-commerce- "Gathering Land” Project Investigation in Jixi County, Anhui 
Province. Newsletter About Work in Rural Areas,13(2014).

[2] Yue Liu, Lulu Min. Research on E-commerce’s Intervention in Rural Land Circulation--Based on Case Study of “Gathering Land”. Journal of Kunming University of Science and Technology (Social Sciences), 16(2016).

[3] Hudong Chen. Rural Land Circulation O2O: One Representative Pattern of Rural E-commerce's Going to Countryside. Business Value, 71(2016).

[4] Haixia Li, Yanning Kang. Comparative Study of Rural Land Circulation Patterns in Internet Age. Co-operative Economy\& Science, 18(2015).

[5] Qing Xue, Leirong Wang. Analysis of Chances and Challenges E-commerce-based Land Circulation Faces. Agricultural Science \&Technology, 6(2016).

[6] Meng Li. Primary Exploration of Land Circulation E-commerce Schemes under The Background of Internet +. Serves of Agricultural Technology, 7(2016).

[7] Guoying Li. Rethinking on Chinese Rural Land Circulation Informatization. National Resource Economics of China, 9(2015).

[8] Jun Ma. Research on Rural E-commerce Development and Rural Surplus Labor Settlement, Journal of China Agricultural Resources and Regional Planning, 2(2016).

[9] Xu Gao. Wang Zheng: Discussion on Internet+ and Chinese Rural Land Circulation and Agricultural Industrialization. Farm Economic Management, 10(2016). 